\title{
Repeat Breeding: A Dent to Dairy Farm Economy
}

\author{
Bhupinder Kaur Khosa* \\ Department of Livestock and Poultry Management, University Institute of Agriculture \\ Sciences, Chandigarh University, Gharaun, Mohali, (Punjab), India \\ *Corresponding author
}

\section{A B S T R A C T}

\begin{tabular}{l}
\hline Ke y w o r d s \\
Repeat Breeding, \\
Early Embryonic \\
Death, Cattle, \\
Buffalo, Artificial \\
Insemination \\
\hline Article Info \\
\hline $\begin{array}{l}\text { Accepted: } \\
\text { 25 June } 2020 \\
\text { Available Online: } \\
\text { 10 July } 2020\end{array}$ \\
\hline
\end{tabular}

\section{Introduction}

Cow or buffalo having healthy and serviceable reproductive tract fails to conceive even after three or four artificial inseminations is known as repeat breeder. It results in financial crisis due to decrease in lactation yield, increased medical expenses, calving time, insemination cost and killing rate in cattle and buffalo (Ariane BonnevilleHébert et al., 2011) (Aghamiri et al., 2020). The major challenge in today's dairy farming is attaining gestation in high yielding cattle in prompt and reasonable expensive way ( $\mathrm{K} \mathrm{A}$ Weigel, 2004). Repeat breeding is one of most crucial genital tract disorder in cattle and buffalo which varies with fecundate failure, early fetal death, region, management and environment. Various investigations have recorded that many components results in repeat breeding syndrome like genital tract infections, any anatomical dys functioning of genital tract, hormonal imbalance and host defense mechanisms against semen (Asaduzzaman et al., 2016). However age, parity, body condition score and high milk production may also influence the manifestation of repeat breeding in cattle. Out of all climatic conditions is the vital element responsible for repeat breeding in cattle and buffalo as heat stress decrease time and vigor of estrus signs results in silent ovulation 
(Singh et al., 2017) (Amjad Khan et al., 2016). While RB is multifactor syndrome but the quality of egg plays an important role in manifestation of this disease as poor quality egg results in low conception rate and early fetal loss (Roberta Machado Ferreira, 2016). However the particular etiologies of RB are not transparent (Muhammad Yusuf et al, 2010). The prevalence of repeat breeding is much greater in crossbred cows $(17.57 \%)$ as compared to buffaloes (12.74\%) and indigenous cows $(8.64 \%)$ (Shailendra Verma et al., 2018). Prolificacy issue in buffaloes are not frequently identified, a very few cases of RB syndrome are investigated as buffaloes are more adoptive to the hot climate conditions as compare to cows (Saraswat and Purohit, 2016). Early embryonic loss occurs in first 42 days of gestation during which implantation and growth of organs takes place. At day 17 upto $80 \%$, between day 17 and 42 near about $10-15 \%$ and after day 42 , $5 \%$ embryonic mortality happens. High yielding and beneficial dairy is based on the good reproductive health of dairy cattle (Rashed Khan Barson et al., 2019). Endocrine secretions of uterus have pessimistic affect due to reduced progesterone and estradiol concentrations in blood of high milk yielding dairy cattle (Dagvajamts, BADRAKH, 2020).

The major challenge in today's dairy farming is attaining gestation in high yielding cattle in prompt and reasonable expensive way (Weigel, 2004). This review article addresses some of the direct or indirect factors responsible for repeat breeding in dairy cattle

\section{Predisposing factors for repeat breeding in dairy cattle}

Various factors are responsible repeat breeding in dairy cattle which includes number of calving, reproductive tract infections, milk yield and semen quality and poor fecundity described below.

\section{Calving season}

Dairy cattle and buffaloes are seasonal breeder animals which show reduced breeding interest in hot season which is reflected by decreased estrus cycle functioning and low fertilization rate. Few researchers describe that temperature has adverse effect on fertility traits in dairy cattle. Incidence of peak calving during monsoon and cold season indicates the highest fertility of dairy animals during months of September to December in India (Abayawasna et al., 2011). LH and progesterone secretion is reduced due to high level of blood prolactin during summer season. The gestation rate and fetal death rates in buffaloes were $58.0 \%$ and $7.3 \%$ during breeding season (Francesco et al., 2012) whereas Nyman et al., (2018) reported $90 \%$ breeding rate and $29 \%$ embryonic death in cattle. Ideal corpus luteum and progesterone level of blood are essential for maintaining pregnancy that reveals the highest occurrence of fetal death and results in repeat breeding (Saraswat and Purohit, 2016).

\section{Metabolic disorders}

High yielding dairy cattle require good quality feed to meet their requirement for maintenance and milk production. The poor feed quality results in high burden of metabolic disorders due to negative energy balance like subclinical ketosis. Body condition score is also associated with repeat breeding (Asaduzzaman et al., 2016). Metabolic disorders have negative effects on prolificacy.

\section{Peri-Parturient Diseases}

Uterine involution includes reduction in size of uterus and removal of remnants of caruncles and renewal of endometrium. Postpartum uterine conditions support the 
microbial infections resulting in delayed uterine involution. Unnatural calving and post partum diseases like endometritis, metritis, dystocia and retained placental membranes are connected with low productivity and fertility results in repeat breeding (Sheldon et $a l .$, 2008). Negative energy balance results in dysfunctioning of host immune system (Adnane et al., 2017) and delayed uterine involution which can raise the post-partum uterine diseases (Abuelo et al., 2014).

\section{Order of Parity and Age of Female}

There is remarkable 0.6 times reduction in rate of fertilization in high yielding dairy cattle and 0.75 times higher than median parity cows (Hay et al., 2019). The occurrence of $\mathrm{RB}$ syndrome is high i.e. $17.07 \%$ in age group of 4 to 6 years and lowest in 6 to $<8(14.15 \%)$ years. It is reported that age has negative impact on prolificacy of animal (Nishi et al., 2018). Both remarkable and non-remarkable effect of parity is observed in buffalo (Thirunavukkarasu and Kathiaravan, 2009).

\section{Nutrition}

Nutrition plays a crucial role in preservation of animal health and fertility. The connection of reproduction and nutrition is matter of rising significance and their relation has been investigated to have involvement for reproduction potential (Ibtisham et al., 2018). Micro nutrients such as $\mathrm{Cu}, \mathrm{Co}, \mathrm{Zn}, \mathrm{Fe}, \mathrm{Se}, \mathrm{I}$, $\mathrm{Mo}, \mathrm{Mn}$ and some macro elements like $\mathrm{K}, \mathrm{Ca}$, $\mathrm{Na}, \mathrm{Cl}, \mathrm{P}$ are found to be very essential for normal livestock growth and performance. Normally roughages and green fodder are deficient in micro and macro minerals (Satapathy et al., 2018). Imbalances and inadequacy of these minerals results in reproductive tract disorder that's why minerals are crucial for vigorous fertility of animal (Ibtisham et al., 2018).

\section{Causes of repeat breeding in dairy cattle}

The causes of repeat breeding syndrome are multi-factor. Etiology of RB is categorized in several ways but failure of fertilization and early fetal death had been precedent classification of causes of repeat breeding. Both male and female, environment and management factors are responsible for repeat breeding which are discussed below.

\section{Female factor responsible for $\mathrm{RB}$}

\section{Ovulation disruption}

Failure and delay in release of ova and cysts on ovary contributes in conception failure. The prevalence of cystic ovaries ranges between $2.7 \%$ to $15.1 \%$ in cow (Cattaneo et al., 2014) and $0.5 \%-1.48 \%$ in buffalo (Raju et al., 2007).

\section{Other Ovarian Pathologies}

Fallopian tube blockage inhibits the fertilization because of hydrosalpinx, pyosalpinx, salpingitis and any growth in fallopian tube. The incidence of oviduct abnormalities varies between $6-15 \%$ of adult cows (Kumar and Singh, 2018) and $0.04 \%$ to $6.4 \%$ in buffaloes (Modi et al., 2011) (Vala et al., 2011).

\section{Metritis and Endometritis}

There are very high chances of microbial contamination within fifteen days of calving due to opening of cervix in cattle. But it is observed that cows are very effective in removing contaminants from uterus but due to high milk production and negative energy balance cows fail to remove the debris and contaminants from uterus resulting into metritis, endometritis. Near about $40 \%$ dairy cattle suffer from puerperal problems (Opsomer and Kruif, 2009). Gahlot et al., 
(2016) studied that prevalence of clinical endometritis was $16.67 \%$.

The quality of oocyte plays an important role in implantation. The impact of post partum diseases on egg quality is not recognized.

\section{Male factors responsible for $\mathbf{R B}$}

Bulls for breeding purposes are selected at early age, trained for semen donation. Selected bulls are culled at any age due to fertility problems which may be hereditary, climatic and poor management of bulls. Similarly as in dairy cows/buffalo environment has major impact on fertility of bull (Khatun et al., 2013). Other factors include collection interval and collection frequency. A single bull can be used for mating 40 cows and thousands of cows by means of artificial insemination that's why fertility of bull is very important. Subfertile bulls can adversely affect the financial conditions and maintenance of livestock/dairy farm (Kastelic, 2013). Quality of semen can arise to repeat breeding syndrome in dairy cattle. Semen quality is most important factor effecting conception rates to artificial insemination and natural mating (Kumar et al, 2014).

As with time use of AI increases in cows and buffaloes most crucial observations for maximum fecundity includes insemination technique, time of insemination and site of semen deposition. AI conception rate depends upon the expertise of the technician ranges amid $25.40 \%$ to $37.83 \%$ in buffaloes (Sharma et al., 2008) and $46.15 \%$ to $54.91 \%$ in cows (Potdar et al., 2018).

\section{Early Embryonic Death}

The death of fetus within first 15 to 21 days of artificial insemination or natural mating is known as early embryonic death. The etiology of early fetal mortality can be divided into infectious and non-infectious types. About $70 \%$ EED occurs due to non-infectious causes (Vanroose et al., 2000). Non- infectious causes include chromosomal abnormality, hormonal balance, disturbance in motherfetus interactions and inbreeding etc. $20 \%$ of total early fetal loss occurs due to chromosomal abnormality in dairy cows (Shah, 2019) (King, 1990). Progesterone produced by the $\mathrm{CL}$ is essential for the establishment and maintenance of pregnancy and deficiency of progesterone results into early embryonic death which does not occur frequently. Infectious causes may be due to proliferation of some specific and nonspecific bacteria, virus and protozoa which results into unfavorable conditions of uterus for implantation of fetus.

The incidence of EED ranges between 20$50 \%$ embryonic and fetal death has been observed in apparently normal healthy animals of all domestic species including bovines (Arthur et al., 1989).

\section{Management strategies for repeat breeder cow and buffalo}

As mentioned earlier climate play important role in fertility of cows and buffaloes during hot humid season cool surrounding should generate through plantation. Good quality feed should be fed should be fed to the animals as per recommendations of bureau of Indian standards. Mineral mixture supplements are essential at the rate of $2 \%$ of ration to full fill the daily requirement of animal. Cull the animals with any congenital reproductive anomaly. Do not inseminate the heifer which is under weight that is less than $300 \mathrm{~kg}$. Only veterinary doctors/ veterinary technician should be allowed to do AI and do not allow any layman to do the same (Bilby and Jordan, 2009). 


\section{References}

Abayawansa, W. D., Prabhakar S., Singh A K and Brar P S. 2011. Effect of climatic changes on reproductive performance of Murrah buffaloes in Punjab: A retrospective analysis. Indian Journal of Animal Sciences. 81 (4): 334-39.

Abuelo, A., Hernández J, Benedito J L, Castillo C. 2014. A comparative study of the metabolic profile, insulin sensitivity and inflammatory response between organically and conventionally managed dairy cattle during the periparturient period. Cambridge University Press. 8 (9): 1516-25.

Adnane, M., Kaidi R, Hanzen C and England G C W. 2016. Risk factors of clinical and subclinical endometritis in cattle: a review. Turkish Journal of Veterinary and Animal Sciences. 41: 1-11.

Aghamiri M S., Ahmadi M R, Haghkhah M, Derakhshandeh A. 2020. Identification of pathogenic microorganisms of repeat breeder dairy cows and a hyperimmune treatment approach. Asian Pacific Journal of Reproduction 1(9): 44-48.

Ahar Ibtisham, Aamir Nawab, Guanghui LI, Ahar Ibtisham, Aamir Nawab, Guanghui LI, and H.H Orteg Arthur, G.H., Noakes, D.E. and Pearson, H. (1989). Veterinary Reproduction and Obstetrics. $7^{\text {th }}$ Edition., E.L.B.S. publication. p: 417.

Asaduzzaman, K. M., Bhuiyan M M U, Rahman $\mathrm{M}$ M and Bhattacharjee J. 2016. Prevalence of repeat breeding and its effective treatment in cows at selected areas of Bangladesh. Bangladesh Journal of Veterinary Medicine. 14 (2): 183-190.

Barson, R. K., Padder S, Sayam A S M, Rahman M M, Bhuiyan M M U, and Bhattacharjee J. 2019. Serum glucose, urea nitrogen, cholesterol, and total proteins in crossbred repeat breeder and normally cyclic cows. Journal of Advanced Veterinary and Animal research. 6(1): 82-85

Bilby, T R., and Jordan E R. 2009. Strategies to improve fertility in the repeat breeder. Texas Dairy Matters. Bonneville-Hébert A, Bouchard E, Tremblay D D., Lefebvre R. 2011. Effect of reproductive disorders and parity on repeat breeder status and culling of dairy cows in Quebec. The Canadian Journal of Veterinary Research. 147-51.

Cattaneo, L, Signorini M L , Bertoli J , Bartolom J A, Gareis N C, Diaz P U, Bo G A and Ortega H H. 2014. Epidemiological description of cystic ovarian disease in argentine dairy herds: risk factors and effects on the reproductive performance of lactating cows. Reproduction in Domestic Animals.

Badrakh, D., 2020. Effect of seminal plasma proteins on the normalization of endometrial epidermal growth factor profile and fertility in repeat breeder dairy cows. Graduate School of Veterinary Medicine, Hokkaido University.

Ferreira, R M., Chiaratti M R, Macabelli C H, Rodrigues C A,Ferraz M L, Watanabe Y F,Smith L C, Meirelles F V, and Baruselli S P. 2016. The infertility of repeat-breeder cows during summer is associated with decreased mitochondrial DNA and increased expression of mitochondrial and apoptotic genes in oocytes. Biology of Reproduction. 94(3): 1-10.

Francesco, S D., Neglia G, Vecchio D, Rossi P, Russo M, Zicarelli L, 2012. Influence of season on corpus luteum structure and function and AI outcome in the Italian Mediterranean buffalo 
(Bubalus bubalis). Theriogenology. 78: 1839-1845.

Gahlot, S C., Kumar S, Kumaresan A, Chand S, Baithalu R K, Lathika S, Patbandha T K and Lathwal S S. 2016. Efficiency of uterine fluid cytology in the diagnosis of subclinical endometritis in the water buffalo (Bubalus bubalis). Reproduction in Domestic Animals. 14.

Iaz, Ibtisham F, Nawab A, Li G, Xiao M, An L, Naseer G. 2018. Effect of nutrition on reproductive efficiency of dairy animals. Medycyna weterynaryjna. $\mathrm{K}$ A Weigel. 2004. Improving the Reproductive Efficiency of Dairy Cattle through Genetic Selection. Journal of Dairy Science 87: 86-92.

Kasteli,c J P., 2013. Male involvement in fertility and factors affecting semen quality in bulls. Animal Frontiers. 3 (4): 20-25.

Khan, A., Mushtaq M H, Ahmed M U D, Hussain A, Khan A, Khan A and Nabi H. 2016. Incidence of repeat breeding in varying breeds of buffaloes and cattle in different climatic conditions in Khyber pakhtunkhwa (pakistan). Buffalo Bulletin: 35(3).

Khatun, M., Kaur S, Kanchan and Mukhopadhyay C S. 2013. Subfertility problems leading to disposal of breeding bulls. Asian-Australasian Journal of Animal Sciences. 26(3): 303-08.

King, W. A., (1990). Chromosome abnormalities and pregnancy failure in domestic animals. Advances in Veterinary Science and Comparative Medicine.34: 229-50.

Kumar, P., and Singh M. 2018. Prevalence of various etiological factors responsible for causing infertility in cows of Himachal Pradesh, India. Explor Anim Med Res. 8(2): 164-67.

Modi, L C., Patel P A, Patel S P, Patel G
G, Joshi A H and Suthar D N. 2011. Prevalence of reproductive problems in Mehsana milk shed area of Gujarat. International Journal of Animal and Veterinary Medicine Sciences. 5: 42442.

Nishi, S A., Sarder M J D, Islam M H, Kamruzzaman S M, Islam M A and Khaton R.. 2018. Factors Affecting the Incidence of Repeat Breeding in Dairy Cows in Rajshahi district, Bangladesh. International Journal of Livestock Research. 8 (10): 90-96.

Nyman, S, Gustafsson H and Berglund B. 2018. Extent and pattern of pregnancy losses and progesterone levels during gestation in Swedish Red and Swedish Holstein dairy cows. Acta Veterinaria Scandinavica. 60:68.

Opsomer, G., and Kruif A D. 2009. Metritis and endometritis in high yielding dairy cows. Vlaams Diergeneeskundig Tijdschrift. 78: 83-88.

Potdar, V V., Marimuthu S and Khadse J R. 2018. Effect of sire, AI operator, lactation number and year of insemination on conception rates in Khillar cattle under field conditions. International Journal of Pure and Applied Biosciences. 6(6): 488-91.

Raju, K G S, Naidu K V, Rao KS. 2007. Incidence of reproductive disorders in buffaloes under field conditions of Andhra Pradesh. Indian Journal of Animal Reproduction. 28: 46-48.

Saraswat, C S., and Purohit G N. 2016. Repeat breeding: Incidence, risk factors and diagnosis in buffaloes. Asian Pacific Journal of Reproduction. 5 (2): 87-95.

Satapathy, D., Mishra S K, Swain R K, Sethy K, Barik S , Sahoo J K and Boitai S S. 2018. Incidence of reproductive problems and blood mineral status of crossbred cattle in kakatpur block of odisha, india. International Journal of 
Current Microbiology and Applied Sciences. 7: 471-80.

Shah, B R., 2019. Factors leading to early embryonic death. Nepalese Veterinary Journal. 36: $118-25$.

Sheldon, M I., Williams J E, Miller N A A, Nash D M, Herath S. 2008. Uterine diseases in cattle after parturition. The Veterinary Journal. 176(1): 115-121.

Singh, M., Sharma A, Sharma A and Kumar P. 2017. Repeat breeding and its treatment in dairy cattle of Himachal Pradesh (India) - A review. Indian Journal of Animal Reproduction.38: (2).

Thirunavukkarasu, M., Kathiaravan G. 2009. Factors affecting conception rates in artificially inseminated bovines. Indian Journal of Animal Sciences. 79: 87175.

Vala, K. B., Panchal M T, Ghodsara D J, Hadiya K K, Trangadia B J, Vagh A A.
2011. Studies on histopathological changes in genitalia of culled buffaloes (Bubalus bubalis). Indian Journal of Veterinary Pathology. 35: 197-99.

Vanroose, G., Kruif, A de, and Van Soom, A. (2000). Embryonic mortality and embryo pathogen interactions. Animal Reproduction Science. 60-61: 131-43.

Verma, S., Srivastava S , Verma R K, Saurabh, Kumar A and Yadav S K. 2018. Incidence of repeat breeding in cows in and around Kumarganj, Faizabad (Uttar Pradesh), India. International Journal of Current Microbiology and Applied Sciences.7:4860-70.

Yusuf, M., Nakao T, Ranasinghe RMS B K, Gautam G, Long S T, Yoshida C, Koike K, Hayashi A. 2010. Reproductive performance of repeat breeders in dairy herds. Theriogenology. 73:1220-29.

\section{How to cite this article:}

Bhupinder Kaur Khosa. 2020. Repeat Breeding: A Dent to Dairy Farm Economy. Int.J.Curr.Microbiol.App.Sci. 9(07): 4085-4091. doi: https://doi.org/10.20546/ijcmas.2020.907.480 